\title{
EN BLOC VERTEBRAL RESECTION FOR PRIMARY AND METASTATIC SPINE TUMORS
}

\author{
RESSECÇÃO VERTEBRAL EM BLOCO DE TUMORES PRIMÁRIOS E METASTÁTICOS \\ DA COLUNA VERTEBRAL
}

\section{RESECCIÓN VERTEBRAL EN BLOQUE DE TUMORES PRIMARIOS Y SECUNDARIOS ESPINALES}

\author{
Maximiliano E. Mereles, ${ }^{1}$ Martín M. Estefan, ${ }^{1}$ Matias G. Petracchi ${ }^{1}$, Julio E. Bassani, ${ }^{1}$ Marcelo Gruenberg, ${ }^{1}$ Carlos A. Sola ${ }^{1}$ \\ 1. Instituto de Ortopedia "Carlos E. Ottolenghi," Buenos Aires, Argentina. Hospital Italiano de Buenos Aires, Buenos Aires, Argentina.
}

\begin{abstract}
Objective: Primary and secondary spine tumors occur frequently and treating them surgically has gained prominence. The objective of this study was to evaluate the outcomes and complications in a series of patients with primary and secondary vertebral tumors treated by en bloc vertebral resection. Methods: A retrospective review of the patients who underwent en bloc vertebral resection between 2004 and 2017 was conducted. Results: During the study period, 16 patients underwent en bloc vertebral resection. They were divided into primary tumor and metastatic tumor groups, 11 being primary tumors and 5 metastatic tumors. The average follow-up period was 95 months (3-156 months). The patients were treated by the same surgical team and the analysis was carried out by an independent observer. Conclusion: In this case series, the results where comparable to those reported in the literature in terms of complications, survival, recurrence and neurological status. It is a demanding surgical technique, with a high percentage of morbidity and mortality, nevertheless, it allows local control and recurrence of the lesion. Level of evidence I; Case Series.
\end{abstract}

Keywords: Spinal Neoplasms; Spine; Lymphatic Metastasis; Thoracic Vertebrae.

\section{RESUMO}

Objetivo: Os tumores primários e secundários da coluna vertebral ocorrem com frequência e o respectivo tratamento cirúrgico tem tido destaque. O objetivo do presente estudo consistia em avaliar os resultados e complicações em um grupo de pacientes com tumores primários e secundários da coluna vertebral tratados através da ressecção vertebral em bloco. Métodos: Uma revisão retrospectiva dos pacientes submetidos à ressecção vertebral em bloco foi realizada entre 2004 e 2017. Resultados: Durante o período do estudo, 16 pacientes foram submetidos à ressecção vertebral em bloco. Eles foram divididos em grupos de tumores primários e tumores metastáticos; 11 eram tumores primários e cinco tumores metastáticos. O período médio de acompanhamento foi de 95 meses (três-156 meses). Os pacientes foram tratados pela mesma equipe cirúrgica e a análise foi realizada por um observador independente. Conclusão: Nessa série de casos, os resultados foram comparáveis aos relatados na literatura em termos de complicações, sobrevida, recidiva e estado neurológico. É uma técnica cirúrgica exigente, com alto percentual de morbimortalidade, porém permite controle local e recorrência da lesão. Nível de evidência l; Série de Casos.

Descritores: Neoplasias da Coluna Vertebral; Coluna Vertebral; Metástase Linfática; Vértebras Torácicas.

\section{RESUMEN}

Objetivo: Los tumores primarios y secundarios en columna vertebral son una entidad frecuente. En el tratamiento de los mismos la cirugía ha ganado protagonismo. El objetivo de este trabajo fue evaluar los resultados y complicaciones en una serie de pacientes con tumores vertebrales primarios y secundarios tratados mediante resección vertebral en bloque. Métodos: Se realizó una revisión retrospectiva de los pacientes intervenidos mediante resección vertebral en bloque desde el año 2004 hasta el año 2017. Resultados: Durante el período evaluado, 16 pacientes fueron intervenidos mediante resección vertebral en bloque. Se los dividió en grupo de tumores primarios y tumores metastásicos, 11 fueron tumores primarios y 5 metastásicos. El tiempo de seguimiento promedio fue de 95 meses (3-156 meses). Los pacientes fueron intervenidos por el mismo equipo quirúrgico y el análisis fue realizado por un obsenador independiente. Conclusión: En la serie, se encontraron resultados comparables a los reportados en la literatura en cuanto a complicaciones, sobrevida, recidiva y estatus neurológico. Es una técnica quirúrgica exigente, con un alto porcentaje de morbilidad y mortalidad, sin embargo, permite el control local y la recurrencia de la lesión. Nivel de evidencia IV; Serie de Casos.

Descriptores: Tumores Vertebrales; Columna Vertebral; Metastasis Linfática; Vertebras Torácicas.

\section{INTRODUCTION}

According to the American Cancer Society, approximately 2400 bone tumors and 10,000 cases of soft tissue sarcomas are diagnosed annually in the United States. ${ }^{1}$ Of these, approximately
$5 \%$ affect the spine. The incidence of primary spinal neoplasias is estimated at between 2.5 and 8.5 per one hundred thousand inhabitants per year.

Study conducted at Hospital Italiano de Buenos Aires. Instituto de Ortopedia y Traumatología "Carlos E. Ottolenghi." Buenos Aires, Argentina.

Correspondence: Instituto de Ortopedia y Traumatología "Carlos E. Ottolenghi." Potosí, 4215, Ciudad Autónoma de Buenos Aires, Argentina. CP 1199. martinestefan@hotmail.com.ar 
Every year, 1.4 million new cases of cancer are registered in the United States. Bone metastases are common, the spine being the most frequently involved location. From $10 \%$ to $30 \%$ of patients with cancer develop symptomatic spinal metastases, although there are post-mortem studies that show spinal metastases in up to $90 \%$ of terminal patients. ${ }^{2-6}$ Improved treatments, as well as an increase in survival time for many types of cancer, have probably also caused the incidence and prevalence of vertebral metastases to increase.

Surgery has gained a lead position in the treatment of these pathologies (primary tumors and spinal metastases), although it is not always the main therapeutic option. ${ }^{7}$

En bloc vertebral resection allows the lesion to be resected with wide margins and without violation of its capsule, which offers a better rate of local and remote control of the disease, thus increasing survival in selected patients.

The objective of this study is to evaluate results and complications in a series of patients who presented primary and secondary spinal tumors and underwent en bloc vertebral resection.

\section{METHODS}

This study was a review of the electronic medical history of the patients who had undergone en bloc vertebral resection by the adult spinal pathology team of this center between January 2004 and December 2017. The patients signed the informed consent form for this study.

All the patients who had undergone en bloc resection to treat primary tumors and metastases of the mobile spine and sacrum were included.

The study variables were tumor type, clinical presentation, level of the lesion, neurological state, ASA score, Tokuhashi score, type of compression and instability caused by the lesion, surgical approach, type of post-resection reconstruction, aggregate pre- and postoperative treatment, complications, percentage of recurrence, and patient survival.

In all cases, preoperative embolization was performed in order to have better control of hemostasis during the resection.

For the analysis of complications the criteria of McDonnell et al. were used, ${ }^{8}$ which divide them by severity into major and minor and by temporal distribution into intraoperative, immediate postoperative (within 30 days following surgery), and late postoperative (more than 30 days following surgery).

For pre- and postoperative assessment imaging studies that included X-ray, MRI, CAT with 3-D reconstruction, PET scan, and bone scintilligram, depending on the case, were used.

With respect to the surgical approach, if using the surgical techniques of resection in bloc later described by Tomita et al.

\section{RESULTS}

During the analysis period, 16 patients who underwent en bloc spinal resection for spinal tumors separated into two groups: 11 cases of primary tumors and 5 cases of metastatic tumors. Nine patients were male and 7 female, with a mean age of 61 years (16-74 years). Mean follow-up time was 95 months (3-156 months). The patients were operated by the same surgical team and the analysis was performed by an independent observer.

Within the primary tumor group, two cases were benign: one case of aneurysmal bone cyst and one enostoma; and the other nine were malignant: 3 cases of osteosarcoma, 2 of chondrosarcoma, and 4 of chordoma. In the group of patients with metastasis, the primary tumors were thyroid in 2 cases, breast in one case, and kidney in the remaining 2 cases.

The initial symptom was axial pain in $100 \%$ of the cases.

In the group of patients with metastasis, 6 en bloc resections, 5 of which were thoracic and 1 lumbar, were performed in the 5 patients.

None of the lesions produced medullary compression in any of the patients, although three of them were unstable according to the Kostuik criteria. ${ }^{9}$

Four patients were classified as ASA II and two as ASA I.

The preoperative Frankel grade was $\mathrm{E}$ in all patients.

The Tokuhashi score resulted in an expected survival of more than one year for all patients (Table 1).

In the metastasis group, all patients had undergone previous interventions, nephrectomy, thyroidectomy, and/or mastectomy, depending on the case, for the treatment of their primary tumors. The 5 patients in this group consulted the team without prior treatment regarding their spinal lesions.

Case number 3 was a 16-year-old patient with a diagnosis of differentiated thyroid cancer, which usually responds well to treatment with radioactive iodine, with high remission rates and a 10-year survival rate close to $90 \%$, but the patient also presented two spinal lesions, which overshadowed the prognosis, even more so given the evidence of poor response of bone lesions to 1-131, which is why a strategy to reduce the tumor mass was proposed to improve the response to iodine therapy and radiotherapy and consequently the survival prognosis. ${ }^{10}$

In terms of the surgical approach: 4 posterior approach en bloc resections and one case of double approach en bloc resection.

For postoperative reconstruction, mesh cage was used in all cases with a bone allograft and posterior instrumentation with pedicle screws and rods.

The cases of metastasis from thyroid cancer received I-131 postoperatively and chemotherapy was performed for metastasis of the breast tumor. (case 4)

Table 1. Demographic data.

\begin{tabular}{|c|c|c|c|c|c|c|}
\hline Patient & Age & Sex & Primary tumor & Level of lesion & Tokuhashi score & Expected survival \\
\hline Case 1 & 52 years & $F$ & Kidney & T8 & 14 points & Greater than 1 year \\
\hline Case 3 & 16 years & $\mathrm{F}$ & Thyroid & $\mathrm{T} 10$ and $\mathrm{L} 2$ & 12 points & Greater than 1 year \\
\hline Case 5 & 66 years & $\mathrm{M}$ & Kidney & T8 & 12 points & Greater than 1 year \\
\hline Case 6 & 37 years & $\mathrm{M}$ & A B Cyst & L5 & $\mathrm{N} / \mathrm{A}$ & $\mathrm{N} / \mathrm{A}$ \\
\hline Case 7 & 53 years & $\mathrm{F}$ & Enostoma & T10 & $\mathrm{N} / \mathrm{A}$ & $\mathrm{N} / \mathrm{A}$ \\
\hline Case 9 & 59 years & $\mathrm{M}$ & Chordoma & L5 & $\mathrm{N} / \mathrm{A}$ & $\mathrm{N} / \mathrm{A}$ \\
\hline Case 10 & 40 years & $\mathrm{F}$ & Chondrosarcoma & L2 & $\mathrm{N} / \mathrm{A}$ & $\mathrm{N} / \mathrm{A}$ \\
\hline Case 11 & 30 years & $\mathrm{M}$ & Osteosarcoma & Sacrum & $\mathrm{N} / \mathrm{A}$ & $\mathrm{N} / \mathrm{A}$ \\
\hline Case 12 & 43 years & $\mathrm{M}$ & Chondrosarcoma & T8 & $\mathrm{N} / \mathrm{A}$ & $\mathrm{N} / \mathrm{A}$ \\
\hline Case 13 & 74 years & $\mathrm{M}$ & Chordoma & L3 & $\mathrm{N} / \mathrm{A}$ & $\mathrm{N} / \mathrm{A}$ \\
\hline Case 14 & 17 years & $\mathrm{M}$ & Osteosarcoma & $\mathrm{T} 2$ & $\mathrm{~N} / \mathrm{A}$ & $\mathrm{N} / \mathrm{A}$ \\
\hline
\end{tabular}


At the end of follow-up, the patient with a T8 spondylectomy from kidney metastasis (case 1) is living in terminally ill status (106 months of survival), the patient with an en bloc resection of T5 for a tumor secondary to thyroid cancer (case 2) received the last control in 2012 and presented disease progression (16 months of follow-up), the other case of metastasis from the thyroid (case 3) who underwent en bloc resection of two vertebrae, currently is in remission from the primary disease (86 months of follow-up), the patient with metastasis from breast cancer (case 4) died in October 2017 (45 months of survival), and the patient in case 5 died three months following surgery from generalized progression of their disease.

In the group of 11 patients with primary tumors, 11 en bloc resections were performed.

The location of the lesion was lumbar in 4 cases, thoracic in 4 cases, cervical in one case, and sacral in the remaining 2 cases.

Regarding the preoperative Frankel score, the case with osteosarcoma in C5 (case 8) had a score of D (deficitary cervicobrachialgia) and the others scored $\mathrm{E}$.

All the patients had a score of ASA II.

No patients had lesions that produced medullary compression or were classified as unstable according to the Kostuik criteria.

The patients with osteosarcoma received preoperative chemotherapy. The patient in case 11 came to the initial consultation having previously been operated at another institution where they performed an intratumor resection from a presumptive diagnosis of chondroblastoma and then 6 months later a recurrence was observed. The anatomopathological diagnosis was reviewed, in which an osteosarcoma was determined, which let to treatment by extensive resection.

In case 10 (chondrosarcoma of L2), a double approach spondylectomy was performed: an anterior approach corpectomy of $L 2$ and an expandable cage and posterior instrumented arthrodesis of T12-L3 (Figure 1).

The Weinstein-Boriani-Biagini (WBB) ${ }^{11}$ system and the WF Enneking $^{12}$ criteria were used for preoperative planning (Table 2).

Among the primary tumors, 6 posterior approach en bloc resections and 5 double approach resections were performed.

The anterior reconstruction was carried out with mesh cage plus bone allograft in 4 cases, with allogeneic structural bone in two cases and an expandable cage plus bone allograft in one case.

Posterior instrumented stabilization was performed in 9 cases, this being the only treatment in two of the patients.

In two cases of resections of the sacrum no instrumentation was used.

The postoperative Frankel in case 9 (Figure 2) worsened from E to $D$ and in case 11 the nerve roots and dura mater were sectioned as part of the oncological resection.

In the two cases of osteosarcoma postoperative chemotherapy was performed.

Complications in both groups: They were classified according to the criteria of McDonnell et al.

Complications were observed in 8 patients (50\%). The complications are summarized in Table 3.
There were 12 major complications in 7 patients and 3 minor complications in 2 patients, one of whom had both major and minor complications (case 9).

The most frequent complication was deep wound infection, reported in 4 patients and requiring antibiotic treatment in addition to surgical cleansing, with germ eradication in all patients. In three
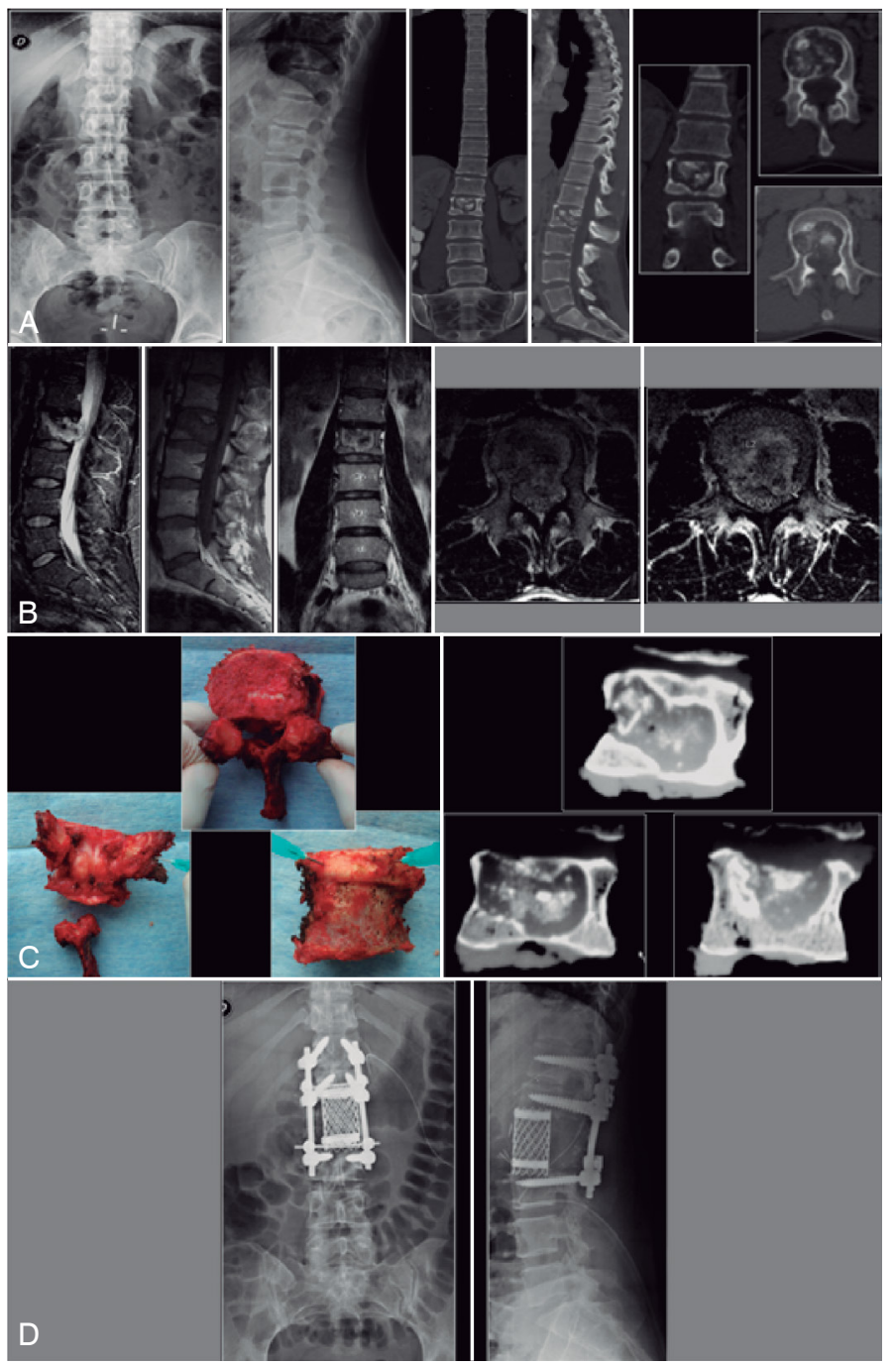

Figure 1. Case 10: F 40 years. Chondrosarcoma of L2. A) X-ray and CAT that show osteolytic lesion in L2. B) MRI that shows heterogeneous lesion in L2. C) Surgical piece. En bloc resection of L2 and CAT reconstruction of the piece. D) Reconstruction via double approach. Anterior approach corpectomy of $L 2$ and expandable cage + posterior approach instrumented arthrodesis of T12-L3.

Table 2. WBB staging and Enneking classification in the primary tumor group.

\begin{tabular}{|c|c|c|c|c|c|c|}
\hline Patient & Tumor & Location & Extension & $\begin{array}{c}\text { Enneking } \\
\text { Staging }\end{array}$ & WBB Staging & Year \\
\hline & Benign & & & & & \\
\hline Case 6 & Aneurysmal bone cyst & L5 & Single & Benign S3 aggressive & $10-3, \mathrm{~B}$ to $\mathrm{D}$ & 2004 \\
\hline \multirow[t]{2}{*}{ Case 7} & Enostoma & T10 & Single & Benign S3 active & 4-9, C to D & 2008 \\
\hline & Malignant & & & & & \\
\hline Case 8 & Osteosarcoma & $\mathrm{C5}$ & Single & Malignant high grade $2 \mathrm{~B}$ & $6-11, B$ to $D$ & 2006 \\
\hline Case 9 & Chordoma & L5 & Single & Malignant Low grade1 B & $3-8, B$ to $D$ & 2009 \\
\hline Case 10 & Chondrosarcoma & $\mathrm{L} 2$ & Single & Malignant Low grade $1 \mathrm{~B}$ & 4-8, A to $E$ & 2010 \\
\hline Case 11 & Osteosarcoma & Sacrum & Single & Malignant High grade $2 \mathrm{~B}$ & 9-1, A to $E$ & 2011 \\
\hline Case 12 & Chondrosarcoma & T8 & Single & Malignant Low grade $2 \mathrm{~B}$ & $8-1, \mathrm{~A}$ to $\mathrm{C}$ & 2012 \\
\hline Case 13 & Chordoma & L3 & Single & Malignant Low grade $2 \mathrm{~B}$ & $2-11 A$ to $D$ & 2014 \\
\hline Case 14 & Osteosarcoma & T2 & Single & Malignant High grade $2 \mathrm{~B}$ & 5-9 A to D & 2014 \\
\hline Case 15 & Chordoma & Sacrum & Single & Malignant Low grade $2 \mathrm{~B}$ & $0-12 \mathrm{~A}$ to $\mathrm{D}$ & 2017 \\
\hline Case 16 & Chordoma & T11 & Single & Malignant Low grade $2 \mathrm{~B}$ & 5-9 A to D & 2017 \\
\hline
\end{tabular}


patients there was a postoperative vertebral fracture proximal to the union and loosening of the implant, which required reoperation with extension of the instrumentation.

Case 16 presented a serious PTE 24 hours following surgery resulting in death despite measures undertaken in intensive care. Another patient (case 5) also presented hypoxia from inflammatory pleural effusion that had to be drained.

Case 11 (previously operated in another center with an erroneous diagnosis), in which a section of the nerve roots was performed as part of the oncological resection, presented monoplegia of the ipsilateral foot. Cases 8 and 9 had transient paresis from neuropraxis with resolution at 6 months. In addition, case 9 also had sphincter and erectile dysfunction following L5 chordoma resection that recovered with urological treatment.

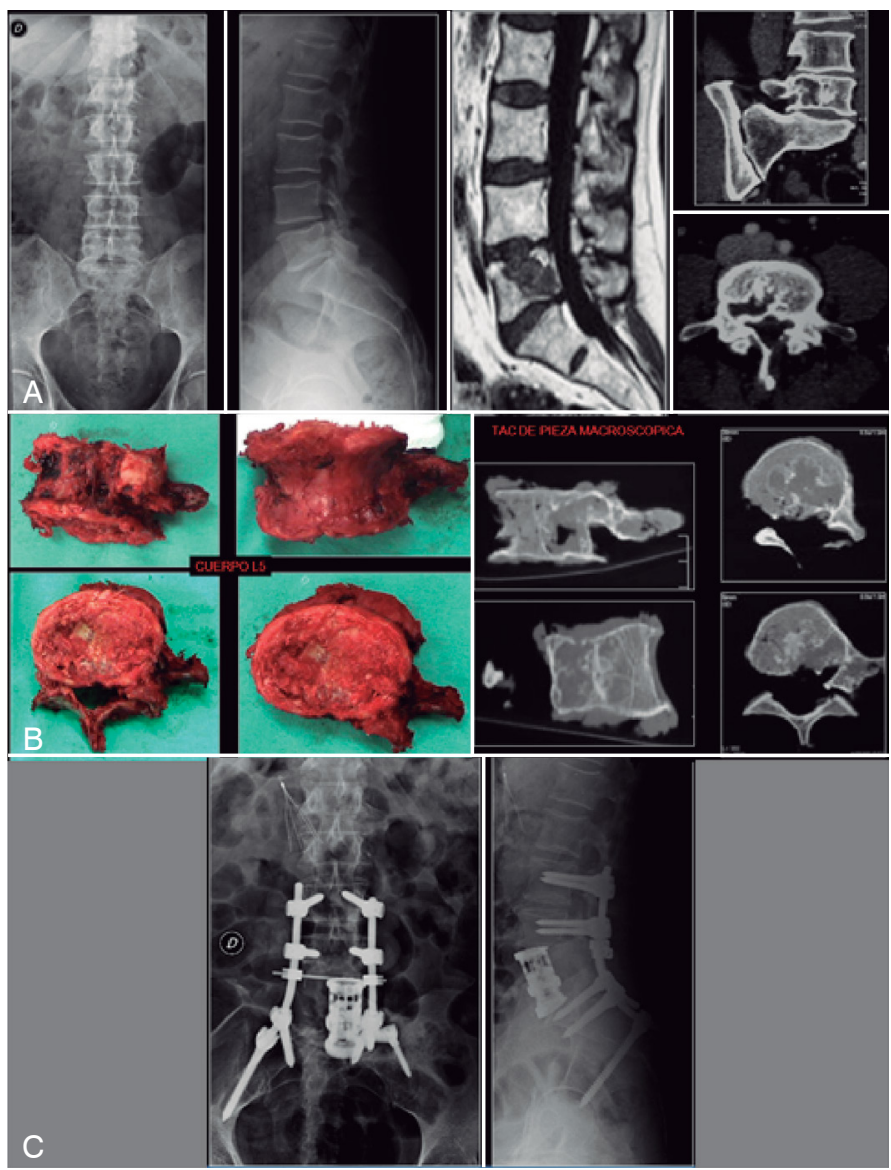

Figure 2. Case 9: M 59 years. Chordoma of L5. A) X-ray, MRI, and CAT showing extensive lesion of L5 body. B) Surgical piece. En bloc resection of $\mathrm{L} 5$ and CAT reconstruction of the piece. C) Double approach reconstruction. Anterior approach corpectomy and expandable cage + posterior approach instrumented arthrodesis from L3 with iliac fixation.
Cases 9 and 13 presented pseudoarthrosis. Case 9 , in which an expandable cage was used, was reoperated by anterior approach to replace the mesh cage and bone graft, causing a vein lesion that had to be repaired with resolution of the condition (Figure 2). The other patient (case 13) was reoperated by posterior approach with reinstrumentation that resolved the problem.

According to the temporal distribution, the complications were divided into:

- Intraoperative: Two cases of neuropraxis and one of sphincter and erectile dysfunction were reported as complications (cases 8 and 9).

- Immediate postoperative (within 30 days following surgery): Four cases of deep infection (cases 2, 4, 9 and 13), three of loosened prosthesis due to vertebral fracture (cases 2, 4 and 13), one serious PTE leading to death of the patient 72 hours after surgery (case 16) and one case of inflammatory pleural effusion (case 5).

- Late postoperative (more than 30 days following surgery): Pseudoarthrosis in cases 9 and 13. In the latter, an L5 chordoma resection was reported in the reoperation of the intraoperative vascular lesion.

As regards the evolution of the oncological disease, the patients with single vertebral metastasis (5 cases), only one presented remission of the disease at the end of the study. The rest presented progression at other locations without local recurrence of the tumor. All the patients had an expected survival based on the Tokuhashi score of more than a year, which was not the case in one patient with renal metastasis. The aggressive progression with rapid deterioration of the general condition of the patient could not have been anticipated from the preoperative studies, including PET/CT, and the patient died 90 days following surgery. The mean survival of the patients was 51 months; patients with primary tumors (11 cases) had a mean survival of 71 months. Of the total group of patients only cases 11 and 12 presented recurrence of their disease (18\%). At the end of the study 8 cases were free of disease. Case 11 was in the final stage of their illness and cases 12 and 16 were deceased.

\section{DISCUSSION}

The indications for en bloc resection include primary malignant stage I or II spinal tumors, aggressive benign tumors (S3) and isolated metastatic tumors that have a long life expectancy. ${ }^{13,14}$

The en bloc resection technique for spinal tumors enables complete oncological resection of the tumor in a single piece, including satellite microlesions in the vertebral compartment, so as to avoid local recurrence. It should be considered especially in patients who have single vertebra involvement or who have a hypervascularized lesion. This procedure is aimed at long-term local control when the patient's expected survival is a year or more. ${ }^{15,16}$

It is a demanding surgical technique that has a high percentage of morbidity-mortality. In the large retrospective study by Boriani et al. ${ }^{17}$ that analyzed a series of 134 en bloc resections of primary tumors, complications were observed in 47 patients (35\%). The percentage of local recurrence was 15.7\% (21 cases) in 63 months of follow-up. Of the 134 cases, 99 had received no prior treatment (referred to as "uncontaminated"), while the others had already

Table 3. Complications

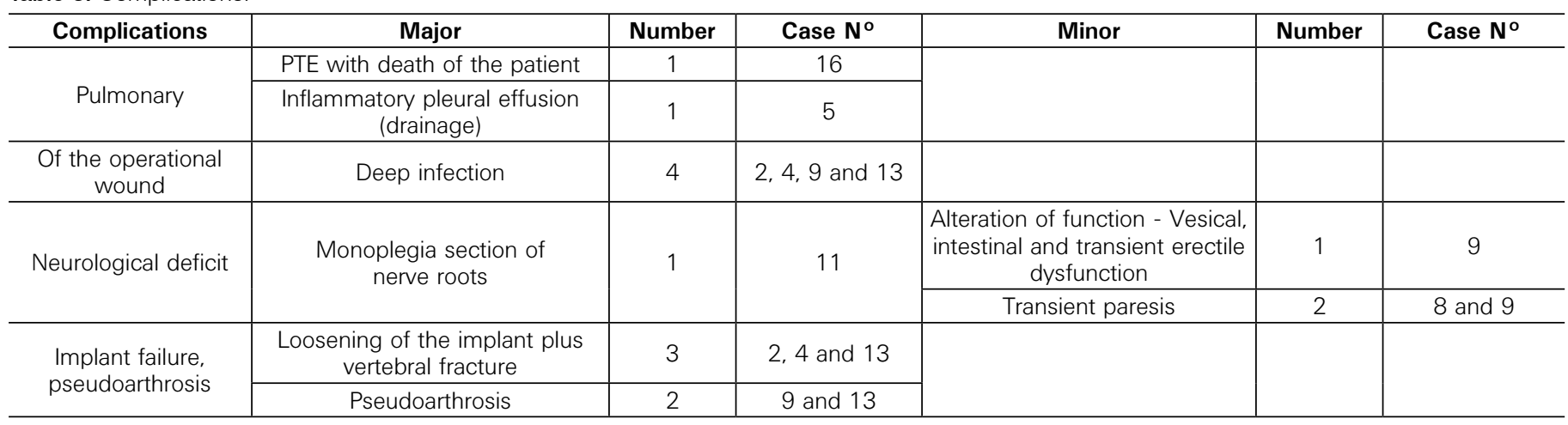


undergone surgery in another center ("contaminated"). Complications and local recurrence were more frequent in the "contaminated" patient group. They found a statistically significant difference between both procedures in terms of the local recurrence rate. The survival, neurological status and incidence of complications results were similar to those observed in our series. The morbidity of excisional surgery is high, however, the results in local control of the lesions are superior.

Most authors believe that en bloc resection is useful for improving the prognosis of aggressive benign and low grade malignant tumors, with a non-negligible percentage of complications in accordance with the magnitude of the primary surgery and even more so in revision surgeries. The main objective of en bloc resection is local control of the disease and prevention of its systemic effects. As such, acceptance of a higher level of morbidity is permitted.

The risk of local recurrence is directly related to the margin of the resection; the epidural extension of the tumor increases this risk. ${ }^{18}$

Decisions about the treatment of spinal bone tumors should be made using oncological criteria. When an en bloc resection is indicated, the possibility of sacrificing neurovascular structures to execute it, as well as the potential morbidity of this procedure should be considered, keeping in mind that the final outcome is better if the overall treatment is performed by a trained team in the same center and that the incidence of complications and recurrences is significantly higher in surgical revisions. ${ }^{18}$

Despite the high risk of a block resection, the benefit in disease control may be more important than any of the morbidity associated with the patient.

Despite the high risk of a block resection, the benefit in disease control may be more important than any of the morbidity associated with the patient.

It should be noted that in our series of 16 cases we had a recurrence rate of $18 \%$ but one of the cases was contaminated for having received previous treatment in another center, with non-oncological criteria.

In our series of 16 cases of en bloc resection for primary tumors (aggressive benign and malignant) and single vertebral metastases, we observed a complication rate of 50\%, representing 12 major complications and 3 minor complications presented in 8 patients. The most frequent complication was deep infection of the surgical wound. There were no complications inherent to the surgical approach in primary surgeries, except in one case of reoperation by anterior approach that suffered pseudoarthrosis and vascular lesion associated with subsequent death in relation to a postoperative DVT.

In the patients with single vertebral metastasis (5 cases), there were no local recurrences of the tumor and most of the patients (4 cases) achieved the expected survival greater than one year as indicated by the Tokuhashi score.

The two cases of recurrence in the series occurred in the group of patients with primary tumors.

\section{CONCLUSION}

This study of en bloc resection for primary tumors and single metastasis of the mobile spine and sacrum yielded results comparable to those reported by authors specialized in oncological surgery in terms of complications, survival, recurrence and neurological status. Because it is a demanding surgical technique with a high percentage of morbidity mortality, adequate and careful selection of the patient is implied.

All authors declare no potential conflict of interest related to this article.

CONTRIBUTION OF THE AUTHORS: Each author made significant individual contributions to this manuscript. MEM and MME wrote the manuscript. MGP reviewed it and guided the discussion, JEB and MG contributed to the editing, and CAS contributed to the editing and final evaluation of the manuscript.

\section{REFERENCES}

1. Cancer Facts \& Figures 2017. American Cancer Society. [Accessed on: 05 jul. 2019] Available on: https://www.cancer.org/content/dam/cancer-org/research/cancer-facts-and-statistics/annual-cancer-facts-and-figures/2017/cancer-facts-and-figures-2017.pdf

2. Schuster JM, Grady MS. Medical management and adjuvant therapies in spinal metastatic disease. Neurosurg Focus. 2001;11(6):e3.

3. Wong DA, Fornasier VL, MacNab I. Spinal metastases: the obvious, the occult, and the imposters. Spine (Phila Pa 1976). 1990:15(1):1-4

4. Ortiz Gómez JA. The incidence of vertebral body metastases. Int Orthop. 1995;19(5):309-11.

5. Loblaw DA, Laperriere NJ, Mackillop WJ. A population-based study of malignant spinal cord compression in Ontario. Clin Oncol (R Coll Radiol). 2003:15(4):211-7.

6. Gasbarrini A, Cappuccio M, Mirabile L, Bandiera S, Terzi S, Barbanti Bròdano G, et al. Spinal metastases: treatment evaluation algorithm. Eur RevMed Pharmacol Sci. 2004;8(6):265-74.

7. Haomiao Li, Gasbarrini A, Cappuccio M, Terzi S, Paderni S, Mirabile L, et al Outcome of excisional surgeries for the patients with spinal metastases. Eur Spine J. 2009;18(10):1423-30.

8. Fidler MW. Radical resection of vertebral body tumours. A surgical technique used in ten cases. J Bone Joint Surg Br 1994:76:765-72. 10.1302/0301-620X.76B5.8083267.

9. Kostuik JP. The development of a preoperative scoring assessment system of metastatic spine disease. Proceeding of The 12th Annual Meeting of North American Spine Society: 1997. p. 22-.5.

10. Muresan MM, Olivier $P$, Leclère J, Sirveaux F, Brunaud L, Klein M, et al. Bone metastases from differentiated thyroid carcinoma. Endocr Relat Cancer. 2008;15(1): 37-49.
11. Boriani S, Weinstein JN, Biagini R. Primary bone tumors of the spine. Terminology and surgical staging. Spine (Phila Pa 1976). 1997:22(9):1036-44.

12. Enneking WF. Musculoskeletal tumor surgery. New York: Churchill Livingstone; 1983. p. 69-122.

13. Boriani S, Biagini R, De lure F, Bertoni F, Malaguti MC, Di Fiore Me, $t$ al. En bloc resection of bone tumors of the thoracolumbar spine: a preliminary report on 29 patients. Spine (Phila Pa 1976). 1996:21(16):1927-31.

14. Tomita K, Kawahara N, Baba H, Tsuchiya H, Nagata S, Toribatake Y. Total en bloc spondylectomy for solitary spinal metastasis. Int Orthop. 1994;18(5):291-8.

15. Tomita K, Kawahara N, Baba H, Tsuchiya H, Fujita T, Toribatake Y. Total en bloc spondylectomy. A new surgical technique for primary malignant vertebral tumors. Spine (Phila Pa1976). 1997:22(3):324-33

16. Tomita K Kawahara N, Murakami $\mathrm{H}$, Demura S. Total en bloc spondylectomy for spinal tumors: improvement of the technique and its associated basic background. J Orthop Sci. 2006;11(1):3-12

17. Boriani S, Bandiera S, Donthineni R, Amendola L, Cappuccio M, De lure F, et al. Morbidity of en bloc resections in the spine. Eur Spine J. 2010:19(2):231-41.

18. Hasegawa K, Homma T, Hirano T, Ogose A, Hotta T, Yajiri Y, et al. Margin free spondylectomy for extended malignant spine tumors: surgical technique and outcome of 13 cases. Spine (Phila Pa 1976). 2007:32(1):142-8.

19. Yao KC, Boriani S, Gokaslan ZL, Sundaresan N. En bloc spondylectomy for spinal metastases: a review of techniques. Neurosurg Focus 2003;15(5):E 6. 